\title{
Accessibility on the Web: Subsidies for the Creation of a New Site for a Master's Course in Diversity and Inclusion
}

\author{
Ana Modestina Pereira Lafetá Cabral' ${ }^{1}$, Luciana Fernandes Rêgo ${ }^{1}$, Cláudia Macedo², \\ Cristina Maria Carvalho Delou ${ }^{1,2,3}$, Helena Carla Castro1,2,3, Neuza Rejane Wille Lima ${ }^{1,2,3^{*}}$ \\ ${ }^{1}$ Professional Master Course in Diversity and Inclusion, IB, Federal Fluminense University, Niterói, RJ, Brazil \\ ${ }^{2}$ Post-Graduation Course in Sciences and Biotechnology, IB, Federal Fluminense University, Niterói, RJ, Brazil \\ 3Post-Graduation Course in Sciences, Technology and Inclusion, IB, Federal Fluminense University, Niterói, RJ, Brazil \\ Email: `rejane_lima@id.uff.br
}

How to cite this paper: Cabral. A. M. P. L., Rêgo, L. F., Macedo, C., Delou, C. M. C., Castro, H. C., \& Lima, N. R. W. (2019). Accessibility on the Web: Subsidies for the Creation of a New Site for a Master's Course in Diversity and Inclusion. Creative Education, 10, 2270-2282.

https://doi.org/10.4236/ce.2019.1010163

Received: July 3, 2019

Accepted: October 28, 2019

Published: October 31, 2019

Copyright $\odot 2019$ by author(s) and Scientific Research Publishing Inc. This work is licensed under the Creative Commons Attribution International License (CC BY 4.0).

http://creativecommons.org/licenses/by/4.0/

(c) (i) Open Access

\begin{abstract}
New technologies, norms, and national and international laws have been created in the last decades in order to make the websites information's accessible for people with disabilities. Thus, based on the principle of the dignity of the human person, as well as the real need to consolidate inclusive public policies in universities, the present work had the objective of analyzing the conceptions of graduates students, university professors, and technical-administrative staff of the Professional Masters Course in Diversity and Inclusion (Curso de Mestrado Profissionalem Diversidade e Inclusão-CMPDI) about inclusion and accessibility on the web. Two questionnaires were applied. The analysis of the conceptions of 106 participants ( $1^{\text {st }}$ questionnaire) guided the development of the new site focused on the needs of its users. This website was prepared following the accessibility guidelines recommended by the Electronic Government Accessibility Model (eMAG). The accessibility of the new site ( $2^{\text {nd }}$ questionnaire) was tested by 89 participants who assign grades from 1 to 10 . The approval of the new site of CMPDI

(http://cmpdi.uff.br/) as greater than $80 \%$. The new tools requested through the second questionnaire were also added to the new site. Thus, the study fulfilled its purposes.
\end{abstract}

\section{Keywords}

Assistive Technologies, Diversity, Inclusion, Blind, Deaf

\section{Introduction}

The duty of governments is to enable equal opportunities for all people. Ac- 
cording to Paulo Freire (2017: p. 25), "respect for one another's autonomy and dignity is an ethical imperative and not a favor we can give each other or not".

In 2015, the Brazilian government normalized equal opportunities with the institution of the Brazilian Law on Inclusion of Persons with Disabilities. This law deals with the legal requirement of eliminating barriers in communications and information that make it difficult or impossible for people who have deficiencies.

For example, the promulgation of Law Decree No. 5626 of December 22, 2005, can be considered the cause of this increase in the number of listeners in the learning of the Brazilian Sign Language-LIBRAS (Brasil, 2005). The art 3 of this decree says "that Libras should be inserted as a compulsory curricular subject in teacher training courses for the teaching profession, at the intermediate and higher levels, and in Speech-Language Pathology courses, public and private educational institutions, federal education system and the education systems of the States, Federal District and municipalities".

After the edition of this decree, other Universities also began to offer the course of LIBRAS. Today, the LIBRAS course is being offered in all Brazilian regions.

In line with the provisions of this policy of inclusion, the Federal University of Santa Catarina (UFSC-https://vestibular2018.ufsc.br/?s=libras) has become a reference in the LBS (LIBRAS) field of teaching, offering undergraduate in "Letras LIBRAS", in the face-to-face, at distance, as well as in the extracurricular modality, aiming to disseminate the teaching and learning of this language to students in the academic environment and to the external community.

In the Federal Fluminense University, the teaching of LIBRAS involves regular courses for undergraduate students and courses for citizens outside the university.

In addition to the universities, there are also programs to support the teaching of LIBRAS, such as the National Program for Proficiency Certification in Translation and Interpretation of the Brazilian Sign Language (ProLIBRAS).

After the year 2011, this program was carried out by the National Institute of Education of the Deaf (Instituto Nacional de Educação de Surdos-INES). This certification in the Brazilian Sign Language is part of the inclusion policy of the federal government. Professionals who pass this examination can work in language teaching and also as interpreters of LIBRAS for Portuguese and vice versa.

For people with disabilities, communication barriers may occur in terms of how they expressed or how they receive messages and information through communication technology systems (Freitas et al., 2015). The choice and motivation to carry out the present study are based on the need to exercise citizenship, respect for differences, and the promotion of equal opportunities in access to information in accordance with the best practices and accessibility guidelines adopted by many countries.

Cabral et al. (2019) conducted a site analysis of 50 Brazilian federal public 
universities to verify the use of techniques and tools that promote accessibility. The authors note that many sites, although they follow the eMAG Accessibility Model, and contain many researched accessibility features; they still have a low accessibility percentage in the eMAG validator. This is due to the fact that accessibility recommendations are still a relatively new topic for Brazilian website developers, who need to improve their understanding of the application of these resources. Thus, the results of this research can help federal public universities gain the understanding of the importance and necessity of following the Accessibility Guidelines in their websites, thus promoting the inclusion of people with disabilities (Brasil, 2019).

The present study addresses the creation of a new inclusive website for the Professional Masters Course in Diversity and Inclusion (Curso de Mestrado Profissional em Diversidade e Inclusão-CMPDI). The creation of the new website was aimed at improving the interactivity and functionality of this course in the virtual environment of the internet, providing more inclusive management among the administration of the course, its students and professors, especially those with sensory disabilities. Therefore, the creation of a website environment that breaks up digital barriers and makes an easy access to the content is essential to promote a social inclusion (Smith, 2008; Freitas et al., 2015).

\subsection{What Is Social Inclusion?}

According to Sassaki (1997: p. 3), "social inclusion is how society adapts itself to include in its general social systems the people with special needs while, simultaneously, allowing them to prepare themselves to assume their roles in society". For this author, society needs to be modified and must understand that it needs to be able to meet the demands of its members by having them as partners in the discussion.

The Universal Declaration of Human Rights establishes that "every person has the right to equal access to the public functions of his country". In Brazil, the law number 9394/1996-Education Guidelines and Bases Law (LDBEN) determined that "education systems will ensure students with disabilities, global developmental disorders, and high skills or giftedness, curricula, methods, techniques, resources educational and specific organizations to meet their needs" (Brasil, 1996).

In addition, the decree number 7611/11 in its art 1, item 1, "the State's duty to educate the target public of special education shall be carried out in accordance with the following guidelines: ensuring an inclusive educational system at all levels, without discrimination and on the basis of equality of opportunities".

Therefore, social inclusion is the way society finds to meet, on an equal basis, the needs of people who have some sensorial, mental, physical or multiple losses capable of promoting the compensation of such losses, independently and autonomously. Thus, providing accessibility in the site of a postgraduate course to all users should contribute to the social inclusion of these individuals, from their custom digital exclusion. 


\subsection{What Is Digital Inclusion?}

Digital inclusion is a general term that addresses the use of Information and Communication Technologies (ICTs) in order to allow the inclusion of all in the information society, aiming at the democratization of technology.

According to Cruz (2004):

"Digital inclusion should favor the appropriation of the technology in a conscious way that makes the individual able to decide when, how and for what to use it. From the point of view of a community, digital inclusion means applying technologies to processes that contribute to the strengthening of economic activities, organizational capacity, educational level and self-esteem of its members, communication with other groups, of their local entities and services and their quality of life" (Cruz, 2004: p. 9).

Following this understanding Pierre Lévy (1999) highlighted:

"What to do? Admittedly, it is necessary to favor in all appropriate ways of ease and smaller of connection costs. But the problem of "access for all" cannot be reduced to the technological and financial dimensions usually presented. It is not enough to stand before a screen, equipped with all the friendly interfaces one can think of, to overcome an inferior situation. First of all, it is necessary to be able to participate actively in the processes of collective intelligence that represent the main interest of cyberspace. The new instruments should serve as a priority to enhance local culture, skills, resources, and projects, to help people to participate in mutual aid groups, cooperative learning groups, etc." (Lévy, 1999: p. 238).

In today's world, it is necessary to provide strategies, support systems and a range of related services for people with special needs (Smith, 2008), such as a fully accessible website (Freitas et al., 2015; Cabral et al., 2019). Therefore, everyone has a condition of access and use, with autonomy and independence of computer systems, information environments and media, regardless of sensory, motor and linguistic conditions of users (Corradi, 2011).

Therefore, faced with the undeniable influence of the Internet on people's lives that today is predominantly digital in virtually all social segments, public or private it is important to make a postgraduate institutional website accessible, improving the quality of teaching, thus guaranteeing the exercise of citizenship.

Thus, the objective of the present study was to analyze the conceptions of graduates, students, teachers and technical-administrative staff of the Professional Masters Course in Diversity (CMPDI) and Inclusion on inclusion and accessibility to subsidize the construction of a new website for this course.

\section{Material and Methods}

In order to achieve the goal of developing an inclusive site, exploratory research of quantitative and qualitative nature was adopted.

The study was carried out in four stages: a) to construct and validate the two questionnaires applied; b) to apply the first questionnaire to analyze the know- 
ledge of accessibility on the web within the staff of the CMPDI; c) to construct the new site for the CMPDI based on the analysis and technical possibilities of the Information Technology Superintendent of the Federal Fluminense University (Universidade Federal Fluminense-UFF); d) to apply the second questionnaire on the accessibility of the new CMPDI website.

Before applied the second questionnaire the website was prepared following the accessibility guidelines recommended by the Electronic Government Accessibility Model (eMAG).

First, a questionnaire with 21 questions was applied from 02/16/2017 to 03/12/ 2017, aiming to analyze the concepts of the CMPDI's staff (graduates students, professors, and technical personnel administrative) on inclusion and accessibility on web sites. The questionnaire was created in Google Drive with open questions related to Appendix A.

Further, the site was built (http://cmpdi.uff.br/) and after a few adjustments, it was made available for testing by the CMPDI's staff between 15/08/2018 to $31 / 08 / 2018$.

For conducting this test the second questionnaire made through the GoogleDrive. We sent an invitation to all members of CMPDI to answer a survey of 17 closed questions (Appendix B). Again six questions were related to the participant's profile as described in Appendix A (data not shown in Appendix B).

Ten questions were applied to the CMPDI staff to access their opinion on the new site. Finally, a question asked them to make suggestions so that the site could be improved.

The answers obtained from the application of the two questionnaires were exported to the Excel v. 2010 for the analysis of the data and elaboration of the figures.

\section{Results and Discussion}

Public education institutions, such as universities and federal institutes, must include all persons with special needs in all their actions, such as providing the tools to provide digital accessibility (Freitas et al., 2015; Cabral et al., 2019). Thus, every effort must be made to provide access to the information contained in its websites to all users, regardless of their sensory, linguistic and motor conditions (Corradi, 2011).

Although digital accessibility is socially important, it is not easily achieved, since there are numerous sensory and motor limitations of users with special needs that need to be compensated by different tools. However, despite the numerous difficulties, digital accessibility must be relentlessly pursued by all societies (Smith, 2008; Ferreira \& Nunes, 2008; Freitas et al., 2015; Cabral et al., 2019). In this sense, the present study describes the analysis of a site accessible by its own users.

The questions about the conceptions of the CMPDI staff on inclusion and accessibility on web sites (Table 1) were answered by 106 participants. The analyses of these responses were strategically divided into four steps. 
Table 1. List of the three most representative answers about three question obtained by the 1st questionnaire regard to website concepts.

\begin{tabular}{|c|c|c|}
\hline & Questions & Answers \\
\hline & $\begin{array}{l}\text { What is an accessible } \\
\text { website? }\end{array}$ & $\begin{array}{l}\text { - "Is a site with easy access and that has clear and objective } \\
\text { instructions that should meet the demand a diverse public" } \\
\text { - "The one in which everyone can access information quickly and } \\
\text { efficiently" } \\
\text { - "The one that has easy navigability, with accurate information and } \\
\text { inclusive tools" }\end{array}$ \\
\hline & What is digital inclusion? & $\begin{array}{l}\text { - "Enable Internet access for all people in an informal way" } \\
\text { - "Bringing information and knowledge to all people" } \\
\text { - "Sites for all people with or without and/or some type of } \\
\text { disability" }\end{array}$ \\
\hline - & $\begin{array}{l}\text { What are the accessibility } \\
\text { features you consider } \\
\text { important in a site? }\end{array}$ & $\begin{array}{l}\text { - "Constant Update" } \\
\text { - "Increase Font" } \\
\text { - } \text { "Videos in LIBRAS with audio and high contrast" }\end{array}$ \\
\hline
\end{tabular}

The first step addressed the outcome of the questions regarding the analysis of the participants' profile. The second step dealt with the participants' relation to internet accessibility. The third step presented the participants' understanding of site concepts and accessibility on the internet. In the fourth step, we approached the participants' opinions on the CMPDI website presented.

\subsection{Analysis of the Participants Profile on the First Survey}

According to the data obtained, the majority of the participants in the first survey $\left(1^{\text {st }}\right.$ questionnaire $)(n=106)$ were females $(84 \%)$, most of whom belonged to the age group 43 to 53 years (minimum and maximum ages 23 and 66 years, respectively, and mean $44.8 \pm 10.1$ ). Most of them were CMPDI students (93.4\%). A total of $5.7 \%$ were professors of the CMPDI, and one person was technical administrative.

These participants declared to be only professors (57\%), public servants (13\%), pedagogues (11\%); the others practicing the following professions: speech therapists, psychologists, psychologists, information technicians, librarians, school principals, lieutenant colonel, instructional design, interpreters and translators of the Brazilian sign language (LIBRAS), archivist, education technician, educational supervisor.

Of the 106 participants in the first study, $8.6 \%$ had some type of disability, the most cited being physical disability $(n=7)$, blind $(n=2)$, deafness $(n=2)$, and dyslexic $(n=1)$.

Most of the participants were fluent in Portuguese (96\%), followed by English (23.8\%) and LIBRAS (14.9\%). In the latter case, both listeners and people with deafness were included.

\subsection{List of Participants Regarding Internet Access}

It was found that $50 \%$ of the participants use the computer to access the internet. 
Tablet and cell phone were the second and third cited.

The great majority of participants access the internet daily (98.1\%). Most participants find it difficult to access the internet all the times (55.2\%). The difficulties described by the participants were mainly related to the failure of downloads, logic in the menus, lack of updating of sites, slowness of the internet, visual pollution of websites, among others. Most participants (82.4\%) do not use specific programs or applications to access the Internet due their disabilities such as blindness or deafness.

Two participants use programs such as JAWS. This program is one of the most used screen readers in the world by people with visual impairment. This is a type of assistive technology with numerous benefits and it makes it possible for visually impaired users to use the computer via shortcut keys.

The Handtalk program was also used by two participants. This application is for mobile devices that converts texts, images and audio to the LIBRAS. It was created by three students from the Federal University of Alagoas (Universidade Federal de Alagoas-UFAL) Mr. Ronaldo Tenório, Mr. Carlos Wanderlan and Mr. Thadeu Luz, and was chosen by the Ministry of Education (Ministério da Educação-MEC) as the standard application on tablets distributed to students and teachers of the public school system throughout Brazil. In 2013, this application was elected by the United Nations as the best social application in the world.

\subsection{Website Concepts}

We selected a list of three most representative answers to each question applied by the $1^{\text {st }}$ questionnaire about the website concepts (Table 1 ). The most representative sentences were related to the contents most cited in at least $60 \%$ of the answers obtained by this questionnaire.

It was noticed that the majority (95\%) of the participants already had the understanding that an accessible site, that is "one that promotes access to information respecting the needs of its users". According to Barbosa \& Silva (2010), "the criterion of accessibility is related to the ability of the user to access the system and to interact with it without the interface imposing obstacles".

The sites most cited by the participants (87\%) as being accessible were the websites of INES whose institutional mission is the production, development and dissemination of scientific and technological knowledge in the area of deafness.

The site of the Benjamin Constant Institute (Instituto Benjamin Constant-IBC) was mentioned by $72 \%$ of participants. This institute is a national reference center in the area of visual impairment, as being considered sites accessible.

It is interesting to note that the INES and IBC websites follow the Accessibility Model in Electronic Government (http://emag.governoeletronico.gov.br/). These sites have the eMAG ASES site validator with $90.83 \%$ and $89.47 \%$, respectively. For more details on eMAG go to 
https://www.governodigital.gov.br/noticias/governo-lanca-ferrames-to-promove r-accessibility-digital.

Other sites were also cited as accessible: the Federal University of Santa Catarina (Universidade Federal de Santa Catarina-UFSC, 88.25\%) and the Curriculum Lattes (72.88\%) that does not follow the eMAG accessibility model. The Bengala Legal website cited by $71 \%$ of participants also does not follow the eMAG model, but has $91.63 \%$ accessibility.

The resources cited by the participants as indispensable to promote accessibility in web sites, such as letter increase, high contrast, navigation shortcuts, among others; meet the recommended resources in the accessibility models of Brazilian and international standards that were analyzed in this work.

Regarding the opinion of the participants in relation to the CMPDI website, they believe that the most suitable location for the main menu of the page is at the top, as well as not be missing on the site, especially updated information, and the possibility of downloading the dissertations, masters' products, and videos in LIBRAS, among others.

The suggestions of the participants about the proper functioning of the CMPDI website regarding the perspective of improvement of the new format were listed in Table 2. These suggestions were the most representative sentences cited in at least $60 \%$ of the answers.

\subsection{Analysis of the Participants Profile on the Second Survey}

In fact, the questionnaire reinforced the understanding of the great need to be included through accessible websites that follow the recommendations of accessibility indicated in national and international legislation, aimed at satisfying all users with or without disabilities.

The profile analysis of the 89 participants revealed that $91 \%$ were female. The participants' age ranged from 28 to 53 years, with a minimum and maximum age of 25 and 65, respectively. Most of them were CMPDI students (89\%). A total of $10 \%$ were professors of the CMPDI and one person was technical administrative.

With regard to their professions, $57.0 \%$ were teachers, $9.8 \%$ were pedagogues and the rest were composed of lawyers, archivists, journalists, administrative technician, cultural producer, phonologies, physiotherapist, nurse, student, and lieutenant colonel.

Regarding the question about whether or not there was a disability, it was found that $16 \%$ of the participants had a disability, $9 \%$ with a physical disability, $5 \%$ with hearing impairment and $2 \%$ with visual impairment.

The profession of the participants focused on education and health; $57.0 \%$ were teachers, 9.8\% were pedagogues and the rest were lawyers, archivists, journalists, administrative technician, cultural producer, phonologies, physiotherapist, nurse, student, and lieutenant colonel.

The new CMPDI website was adjusted based on the observations of 89 participants that answer the $2^{\text {nd }}$ questionnaire. The site address was made available to 
Table 2. List of 20 responses obtained by the $1^{\text {st }}$ questionnaire for opinion on the proper functioning of the CMPDI website.

\section{Answers}

1) "I think it's important to keep the site up-to-date".

2) "Insert a fixed link with all information in LIBRAS and audio. If there was I did not visualize".

3) "Disclosure of CMPDI events".

4) "Organize site downloads in a download library".

5) "As also offer distance learning through Moocs (open and massive online course) and DL Mooc (open and massive online course taught at a distance)".

6) "Have a talk with us that works, updated forms and no errors".

7) "One talk with us on the page would be good for students on secretarial matters".

8) "Update every CMPDI website periodically".

9) "Put products from the master's research. Being updating. Go adding the works. Separated the dissertation by years: 2013, 2014, 2015, ...".

10) "Make the screen look brighter and have more objective information with more spacing between the links".

11) "Information on student grades and assessments".

12) "Make clear where is the possibility of doing download".

13) "Be constantly updated".

14) "Could the background color (white) change to a more intense color"?

15) "The virtual secretary should have a link only on the side flap. The others should be organized inside the page that opens. I believe that updating information and functionality is the key. The site could have a direct link with Plataforma Brasil and the possibility of sending documents, so that it is accessible to the student when it was received and the process of the same, until the final result. It would also be interesting a space for suggestions and who knows, a virtual service to get some more frequent questions. The clarity in information is the key".

16) "Each individual is unique. For this reason, it is necessary to be aware that not every person theoretically without disability will have more facility than a disabled person; not everyone who is deaf is proficient in LIBRAS and understands written content; not every blind man uses BRAILLE; physical disability then varies even more".

17) "Make available the events that occur in the course on the CMPDI page".

18) "Links to other sites on diversity and inclusion".

19) "I could fix the section and give it a revival, I feel that sometimes it's kind of erased".

20) "Masters students should have a password to withdraw statements from events conducted by the master's degree and completion of disciplines making the site functional and not bureaucratic or simply promotional".

the participating public for them to make assessments and those grades it from 1 to 10 (Table 3).

As the results of the evaluations (Table 3), the site was positively analyzed. It was verified that the site was evaluated in a very positive way, since more than $80 \%$ of the evaluators rated notes from 7 to 10 in all analyzed items. The average of grades varied from $8.60 \pm 1.94$ for the question: "Evaluate the accessibility of this site" to $9.52 \pm 1.00$ for the question: "Evaluate how likely are you to access the site again?"

The results obtained are in agreement with Borges et al. (2013) which said that it is relevant "...the construction of inclusive school committed to the students diversity, especially with people with educational special needs. It should seek to attend this diversity which include both educational agents as well as the beneficiaries of this inclusive education taking into account this disability word." (Borges et al., 2013: p. 420). 
Table 3. Results of notes [average and standard deviation $( \pm \mathrm{SD})$ ] and percentual of answers (\%) per group of notes for the ten questions applied to evaluate the site.

\begin{tabular}{|c|c|c|c|c|c|c|}
\hline \multirow{2}{*}{ Questions } & \multirow{2}{*}{$\begin{array}{l}\text { Average } \\
( \pm \mathrm{SD})\end{array}$} & \multicolumn{5}{|c|}{ (\%) of answers per group of notes } \\
\hline & & $1-2$ & $3-4$ & $5-6$ & $7-9$ & 10 \\
\hline 1) Evaluate the layout of the site & $\begin{array}{c}8.76 \\
( \pm 1.68)\end{array}$ & 1.1 & 2.2 & 4.5 & 47.3 & 44.9 \\
\hline 2) Evaluate the text of the site & $\begin{array}{c}8.97 \\
( \pm 1.36)\end{array}$ & 0 & 2.2 & 2.2 & 47.3 & 48.3 \\
\hline 3) Evaluate the accessibility of this site & $\begin{array}{c}8.60 \\
( \pm 1.94)\end{array}$ & 2.2 & 3.3 & 5.6 & 46.2 & 42.7 \\
\hline $\begin{array}{l}\text { 4) Evaluate the quality of information provided } \\
\text { on this site }\end{array}$ & $\begin{array}{c}8.96 \\
( \pm 1.46)\end{array}$ & 0 & 2.2 & 4.4 & 41.7 & 51.7 \\
\hline $\begin{array}{l}\text { 5) Evaluate the usefulness of the links displayed } \\
\text { on the site }\end{array}$ & $\begin{array}{c}9.24 \\
( \pm 1.30)\end{array}$ & 0 & 2.2 & 1.1 & 34.8 & 61.9 \\
\hline $\begin{array}{l}\text { 6) Evaluate the site layout helps you find what } \\
\text { you need }\end{array}$ & $\begin{array}{c}9.07 \\
( \pm 1.46)\end{array}$ & 0 & 3.3 & 1.1 & 38.2 & 57.4 \\
\hline $\begin{array}{l}\text { 7) Evaluate how this site meets your } \\
\text { expectations }\end{array}$ & $\begin{array}{c}8.90 \\
( \pm 1.46)\end{array}$ & 0 & 1.1 & 6.8 & 43.8 & 48.3 \\
\hline $\begin{array}{l}\text { 8) Evaluate how the site compares to your idea } \\
\text { of an ideal website }\end{array}$ & $\begin{array}{c}8.63 \\
( \pm 1.50)\end{array}$ & 0 & 1.1 & 3.8 & 43.8 & 51.3 \\
\hline $\begin{array}{l}\text { 9) Evaluate how likely are you to access the site } \\
\text { again }\end{array}$ & $\begin{array}{c}9.52 \\
( \pm 1.00)\end{array}$ & 0 & 0 & 1 & 20.9 & 78.1 \\
\hline $\begin{array}{l}\text { 10) How likely are you to use the site as your } \\
\text { primary resource for information about CMPDI }\end{array}$ & $\begin{array}{c}9.22 \\
( \pm 1.49)\end{array}$ & 0 & 3.4 & 3.3 & 23.6 & 69.7 \\
\hline
\end{tabular}

Thus, the acceptance and inclusion of diversity must be promoted not only in the educational environmental but in all segments in order to achieve a pluralistic, democratic, and socializing society (Freitas et al., 2015). The construction and continuous updating of an inclusive site represents one of several paths of this long journey.

\section{Final Considerations}

In the reality of the 21 st century, it is essential that schools, universities and educational institutions allow everyone to find essential information for their educational training through their websites. Thus, access portals should not be restrictive environments (Freitas et al., 2015; Cabral et al., 2019). Thus, these sites should not be restrictive environments but adapted for people with special needs, analogously to the educational institution physical/real locations (Smith, 2008). The accomplishment of this work promoted the awareness about the importance of accessibility in the sites of the postgraduate course, awakening several perspectives for the accomplishment of future works, in order to consolidate this understanding. In this way, the new accessible sites that are built must be tested by their users and always corrected based on these evaluations.

At first, the most important is to correct the errors presented in the site by the accessibility validator of the eMAG Model. It is important to know that these corrections had already been initiated by the technicians of the Superintendence 
of Information Technology of Fluminense Federal University.

It is necessary to focus on the constant adaptation of the documents available on the site to the accessibility guidelines, for example, the configuration of the forms, the PDF documents, which, often because they are not in the proper form, end up causing barriers of accessibility.

Many suggestions provided by the participants regarding the improvement of the new site were of great relevance in the construction of this one. It is also known that other needs could arise over the years; however, we are aware that this process of keeping the site accessible is continuous work, where only the practice can guarantee a positive result.

\section{Acknowledgements}

We thank all the participants that analyzed the site and help us to improve the communication among persons that participle or are interested in the Professional Master's Course in Diversity and Inclusion.

\section{Conflicts of Interest}

The authors declare no conflicts of interest regarding the publication of this paper.

\section{References}

Barbosa, S., \& Silva, B. (2010). Interação Humano-Computador. [Human-Computer Interaction]. Brasil: Elsevier.

https://pt.scribd.com/document/372868645/ALTERADO-Simone-Barbosa-and-BrunoSilva-Interacao-Homem-Computador

Borges, A. C., Oliveira, E. C. B., \& Pereira, E. F. B. B. (2013). Reflexões sobre a inclusão, a diversidade, o currículo e a formação de professores. [Reflections on Inclusion, Diversity, Curriculum and Teacher Training]. VII Congresso Brasileiro Multidisciplinar de Educação Especial, Londrina PR.

http://www.uel.br/eventos/congressomultidisciplinar/pages/arquivos/anais/2013/AT01 -2013/AT01-040.pdf

Brasil (1996). Law Decree 9,394, December 20, 1996. http://www.planalto.gov.br/ccivil_03/LEIS/L9394.htm

Brasil (2005). Decreto de Lei No. 5.626 de 22 de Dezembro de 2005. [Brazil, Law Decree No. 5,626 of December 22, 2005]. http://www.planalto.gov.br/ccivil_03/_ato2004-2006/2005/decreto/d5626.htm

Brasil (2019). Accessibility Model in Electronic Government, Version 3.1, April 2014. https://www.governodigital.gov.br/transformacao/cidadania/acessibilidade/emag-mod elo-de-acessibilidade-em-governo-eletronico

Cabral, A. M. P. L., Delou, C. M. C., Castro, H. C., \& Lima, N. R. W. (2019). Análise no sites de 50 universidades públicas federais brasileiras. [Analysis on the Websites of 50 Brazilian Federal Public Universities]. In N. R. W. Lima, L. T. Perdigão, \& C. M. C. Delou (Eds.), Pontos de Vista em Diversidade e Inclusão (Vol. 6, pp. 46-53). ABDIn, Niterói, RJ.

https://www.researchgate.net/publication/334279948_Pontos_de_Vista_em_Diversida de_e_Inclusao_Volume_6 
Corradi, J. A. M. (2011). Acessibilidade em ambientes informacionais digitais: Uma questão de diferença. [Accessibility in Digital Information Environments: A Matter of Difference]. São Paulo: Editora Unesp.

Cruz, R. (2004). O que as empresas podem fazer pela inclusão digital. [What Companies Can Do for Digital Inclusion]. São Paulo: Instituto Ethos.

Ferreira, L, S. B., \& Nunes, R. R. (2008). E-usuabilidade. [E-Usability]. Rio de Janeiro: LTC.

Freire, P. (2017). Pedagogia da autonomia: saberes necessários à pratica educativa. [Pedagogy of Autonomy: Knowledge Necessary for Educational Practice] (55th ed.). São Paulo, Paz e Terra.

Freitas, C. G., Delou, C. M., de Souza, S. C., Braga, M. N., \& Castro, H. C. (2015). People with Special Needs and the Accessibility of Websites of Educational Institutions: Using the Brazilian System to Point to a Current and Problematic Global Issue. Creative Education, 6, 2021-2027. https://doi.org/10.4236/ce.2015.618207

Lévy, P. (1999). Cibercultura. [Cyberculture]. São Paulo : Editora 34.

Sassaki, R. K. (1997). Inclusão: Construindo uma sociedade para todos. [Inclusion: Building a Society for All]. Rio de Janeiro: WVA.

https://www.passeidireto.com/arquivo/32006909/inclusao-construindo-uma-sociedade -para-todos

Smith, D. D. (2008). Introdução à educação especial: Ensinar em tempos de inclusão. [Introduction to Special Education: Teaching in Times of Inclusion] (5th ed.). Porto Alegre: Artmed. 
Appendix A. The First Questionnaire Applied to Analyze the Conceptions of the CMPDI's Staff on Accessibility on the Web with Open Questions

\begin{tabular}{|c|c|}
\hline Categories & Questions \\
\hline \multirow{7}{*}{ Profile of participants } & 1) How old are you? \\
\hline & 2) What is your gender? \\
\hline & 3) When did you graduate? \\
\hline & 4) What is your profession? \\
\hline & 5) What is your CMPDI staff category? \\
\hline & 6) Do you have any disabilities? \\
\hline & $\begin{array}{l}\text { 7) If you answered yes previously, please tell us what your disability is. } \\
\text { 8) In which languages are you fluent? }\end{array}$ \\
\hline \multirow{4}{*}{ Web access } & 1) What technology do you use to access the Internet? \\
\hline & 3) How often do you access the Internet? \\
\hline & 4) Do you find it difficult to access web sites? \\
\hline & 5) If you answered yes previously what are the difficulties? \\
\hline \multirow{3}{*}{$\begin{array}{c}\text { Concept of an accessible } \\
\text { website }\end{array}$} & 1) What is an accessible website? \\
\hline & 2) Do you know of any accessible websites? Please, exemplify. \\
\hline & 3) What is digital inclusion? \\
\hline \multirow{5}{*}{$\begin{array}{l}\text { Opinion on accessibility } \\
\text { on websites }\end{array}$} & 1) What are the most important features of a website? \\
\hline & 2) Are there fully accessible? \\
\hline & 3) What accessibility features do you consider important in a website? \\
\hline & 4) Do you use any program/application to access web sites? \\
\hline & $\begin{array}{l}\text { 5) If you answered yes previously please indicate, which pro- } \\
\text { gram/application do you use? }\end{array}$ \\
\hline
\end{tabular}

Appendix B. The Second Questionnaire Applied to Evaluate the Site for the CMPDI with Closed Questions. The Following Condition was Proposed: "Please Rate the Site for the Items Listed Below, Indicating the Grade from 1 to 10 . The Scale of Values Varied from 1 = VERY BAD to 10 = EXCELLENT"

Items
1) Evaluate the layout of this site.
2) Evaluate the texts of this site.
3) Evaluate the accessibility of this site.
4) Evaluate the quality of the information provided on this site.
5) Evaluate the usefulness of the links displayed on the site.
6) Evaluate the site layout helps you find what you need.
7) Evaluate how this site meets your expectations.
8) Evaluate how the site compares to your idea of an ideal website.
9) How likely are you to access the site again?
10) How likely are you to use the site as your primary resource for information about CMPDI? 